\title{
EVALUATION OF THE BODY CONDITION OF HIGH YIELDING COWS **
}

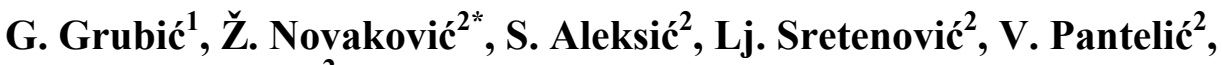 \\ D. Ostojić-Andrić ${ }^{2}$, \\ ${ }^{1}$ Faculty of Agriculture, Belgrade \\ ${ }^{2}$ Institute for Animal Husbandry, Belgrade-Zemun \\ ${ }^{3}$ PKB Agroekonomik, Belgrade \\ * Corresponding author: Željko Novaković, e-mail: titan@planet.co.yu \\ ** Original scientific paper - Originalni naučni rad
}

Abstract: Problems which relate to production, health and reproduction in herds of high yielding cows very often occur due to insufficient knowledge and monitoring of energy reserves in cow organisms. Many researches and practical experiences in this field indicate significant relation between body condition and achieved results in production. Body condition of heads of cattle in certain stages of production cycle is important parameter of applied nutrition, but also entire technological procedure. In countries with developed cattle production, evaluation of body condition has for several years been main component of production practice on farms. It is considered that condition is very reliable indicator of the nutrition status and energy balance in the organism. Body condition score is subjective and practical method which enables precise assessment of deposited fat in the cow organism by observing and touching previously determined body regions and fields.

There is considerable variability of the condition of cows in different stages of production cycle. Body condition of high yielding cows often comes out of the frame of optimal values for certain stage of production cycle. Decrease of production, disorders in health condition and fertility of cows indicate the nature of relation between inadequate body condition and stated problems. Shape and strength of the relation between production results and body condition score confirms its reliability. This is all indication of the need for wider application of this evaluation system. Based on body condition score, beside other important factors in the production cycle, there is realistic possibility to achieve more efficient production of milk from the aspect of energy. Main purpose of this paper was to present how the application of methods for body condition score and its significance for production practice can be functional.

Key words: body condition score, energy balance, nutrition, production, health, fertility 


\section{Introduction}

There is considerable number of problems in milk production, reproduction results and health condition of high yielding cows which can be linked to applied technology of nutrition. Basis of the problem in most of the cases is lack of balance in nutrition from the quantitative and qualitative aspect.

Important question in technology of nutrition of high yielding cows is the amount of energy at disposal (food, fat deposits, muscles) in key stages of the production cycle (dry period and early lactation). Energy deficit in critical periods of production cycle can lead to serious disorders in production, health and reproduction (Lotthamer, 1991; Adamović et al., 1992).

Energy balance is relation between consumed energy and energy used on maintenance of the organism and production. If energy requirements are not satisfied, then organism is using body reserves of fat tissue (Morow, 1975, Domecq et al.,1997). Energy balance is negative in early, and positive in later lactation period.

In the initial stage of milk production, the most critical moment is period of maximum daily production. At the peak of lactation the negative balance is most explicit. In that lactation period the high values are realized by cows with top milk production. High loss of energy to the detriment of body reserves of fat tissue represents great burden to the cow metabolism. Intensive mobilization of energy from fat depots is related to changes in the function of lymphocytes and incidence of various infections in the period after calving (Lacetera et al., 2005).

Providing of adequate amount of energy for each stage of production cycle is complex requirement, which can be satisfied through sufficient quantities and adequate quality of dry matter deriving from forage and concentrated feeds.

Cows in fattening condition have longer periods from the moment when lactation peak was achieved to maximum consumption of dry matter from daily ration (Garnsworthy $i$ Topps, 1982). Duration of negative energy is longer than the period of growth and reaching of top milk yield. Subsequent to realization of maximum daily milk production comes decreasing trend in lactation. During early lactation, cows in fattening condition have great losses in body weight compared to cows of weaker body condition.

Older cows in fattening conditions consume considerably less dry matter compared to cows of optimum body condition. Long period between realized peak of lactation and realization of maximum consumption of dry matter in the period of high milk production and poor appetite increases the consumption of body fat reserves. 
Possibilities for more favorable fertility results are in the improvement of the environment factors, especially through nutrition and its effect on body condition, which cause increase of the percentage of gravidity in certain seasons (Loeffler, et al., 1999).

\section{Body condition score system}

Providing of energy in nutrition of high yielding cows during the period of milk production and dry period has dynamic character. Maintaining of condition status of cows within normal values through adequate nutrition is complex requirement in all production periods and stages.

Body condition of high yielding cows is related to many factors of the environment which influence the intake of dry matter of the ration. These factors are firstly food at the disposal, balance of feeds in the ration, feeding method, effects of the environment (stress), different physical factors and practice in management of the cattle farm (Grubic et al. 1999; Hutjens, 2005; Grubic et al., 2005). Technology of nutrition is key factor for normal production and reproduction cycle (Grubić and Adamović, 2003).

Evaluation of the body condition (BCS) is a subjective method for determination of the quantity of subcutaneous fat. BCS is useful tool for management of dairy herd of cattle. Ideal body condition is rank in function of flow and stage of lactation (Ferguson, 1994). BCS is used for determination of body reserves in sheep, fattening cattle and dairy cows (Lowman et al., 1976; Grubić et al., 1997; Mekić et al., 2001). Estimation of the energy reserves in the organism determined through EBS basically represents the nutrition status of the head of cattle valued through deposited fat tissue, and body frame and weight of the head of cattle are of secondary importance (Ducker et al., 1985). Decrease of energy intake for production of milk by different feeds leads always to mobilization of energy reserves in organism. Dry cows need to use the surplus of body reserves as a support for production of milk in early lactation when the amount of energy consumed through food is less than energy leaving the organism through milk (Ferguson, 1994, Grubić et al., 2003). Changes in the condition of high yielding cows during first few weeks of lactation can be important indicator of the degree of metabolic burden (Pryce and Løvendahl. 1999).

There are several systems for obtaining of BCS for high yielding cows which are basically similar. They are precisely presented in literature and widely used in practice. Two systems of BCS distinguish them selves from the others and are presented in the literature (Wildman 1982, Edmonson, 1989). Ranking of heads of cattle is from 1 (skinny) to 5 (fat). Ranks increase equally/evenly by 0,25 points. In later period details required for these systems 
are precisely explained, developed and expended for use in both systems of BCS (Ferguson, 1994). Increase of body condition by 0,25 of evaluation above the level of 3,75 leads to decrease in the intake of dry matter by approximately 1,5 to $2 \%$ (Roseler, 1998).

Body condition score is based on observation and feeling/touching of certain parts of the animal body. Animal is given points based on previously established numerical scale. Average value of the sum of all body condition scores (body condition score-BCS) for all parts (regions and sections) on the body of the animal included into model (evaluation system), represent an aggregate indicator of the condition of cows. There is optimal value of the body condition score with limit values in regard to minimum and maximum for every stage of the production cycle (Wildman, 1982).

\section{Application of the body condition score system}

One of the BCS systems for cows which is very important for practice is the American Virginia system modified according to Edmodson. BCS system is created in the form of map (chart) for evaluation of high yielding cows. It was prepared after detailed review of procedures used for BCS in Great Britain, Australia, New Zealand and USA. Original models which were analyzed later are adjusted for use in practical conditions based on concrete experiences in production conditions. Adjustment process for Australian and American method was repeated until the required level of harmonization on the entire map surface has been achieved. Beside the diagram is the text which clearly and precisely explains gradual changes in BCS. In this way the dependence on descriptive evaluation which was in use in previous period was reduced.

Map is precisely prepared for every body region and field/part which can be considered important in total BCS of cow. Three large body regions (loin, rump and tail head) are divided into eight fields on the body of cow (loin has four fields; rump has three fields and tail head has one field). Every body field is scored individually and used as parameter of body condition. Every head of cattle is scored individually on changes of the level of score from 1 to 5 . Continuously the increase by 0,25 parts of the score is used. Whole system of BCS is functioning with 17 levels within the total score scale, observed from the minimum score of 1 to maximum score of 5 . Score 1 shows skinny condition. Score 5 shows extremely fattening condition. Every phase of production cycle has its optimal score.

There are certain dimensions of application of BCS in dairy herds. One of them is that BCS follows changes of body condition according to lactation stages. The second is that from month to month we can compare the body condition of animals in the herd. Third is the possibility of comparison of 
body condition according to technological groups of dairy cows. Difference in BCS between groups can influence differences in milk quantity within lactations. In this way the reliability of selection of criteria for forming of technological groups of cows on the farm is increased.

Table 1. Recommended BCS of cows in different phases of production cycle

\begin{tabular}{|c|c|c|c|c|}
\hline \multirow{2}{*}{ Production cycle phase } & \multirow{2}{*}{ Duration } & \multicolumn{3}{|c|}{ Body condition score } \\
\cline { 3 - 5 } & (days) & Aim & Min & Max \\
\hline Calving & & 3,50 & 3,25 & 3,75 \\
\hline Early lactation & 1 to 30 & 3,00 & 2,75 & 3,25 \\
\hline Lactation peak & 31 to 100 & 2,75 & 2,50 & 3,00 \\
\hline Middle of lactation & 101 to 200 & 3,00 & 2,75 & 3,25 \\
\hline Late lactation & 201 to 300 & 3,25 & 3,00 & 3,75 \\
\hline Dry period & $>300$ & 3,50 & 3,25 & 3,75 \\
\hline Dry off & & 3,50 & 3,25 & 3,75 \\
\hline
\end{tabular}
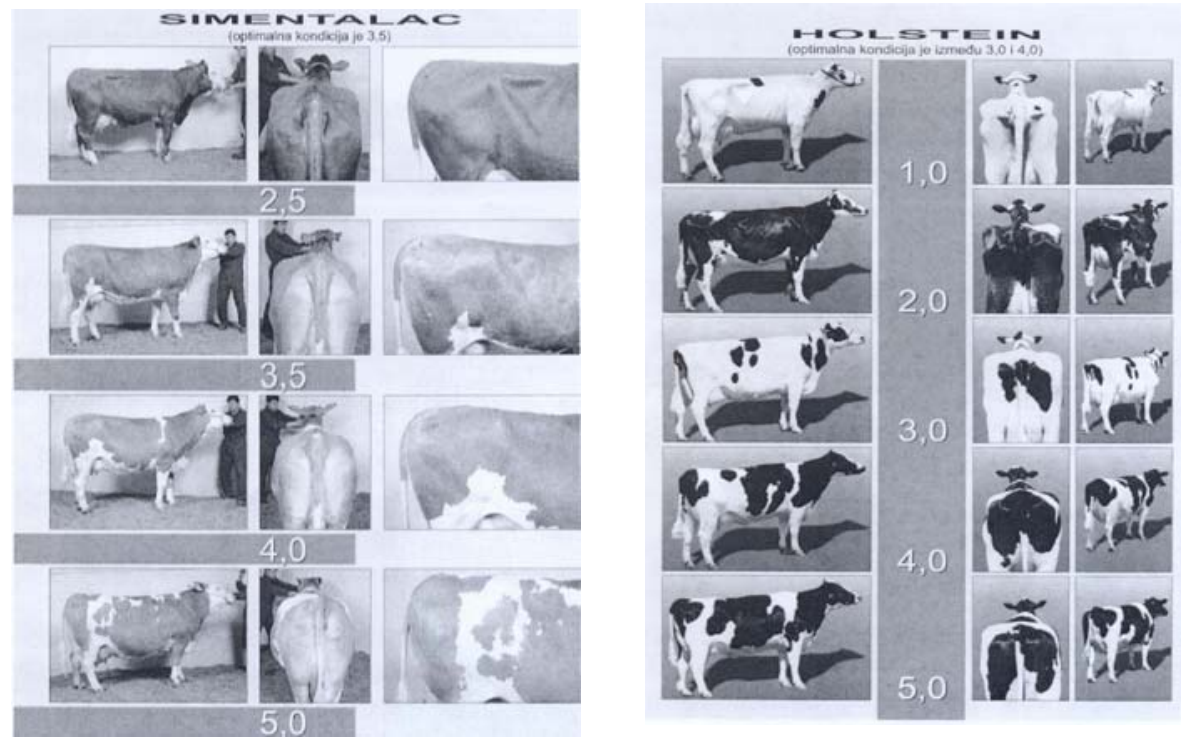

Figure 1. Body condition score of Simmental and Holstein-Friesian cows 
In evaluation of body condition we monitor each individual cow from dry period and on through entire period of lactation. Score system enables continuous individual monitoring of the life of animal through time and production process. BCS enables us to establish the changes in the cow herd on the level of individual and average body condition score. It is especially important to monitor body condition before and during critical periods of production cycle.

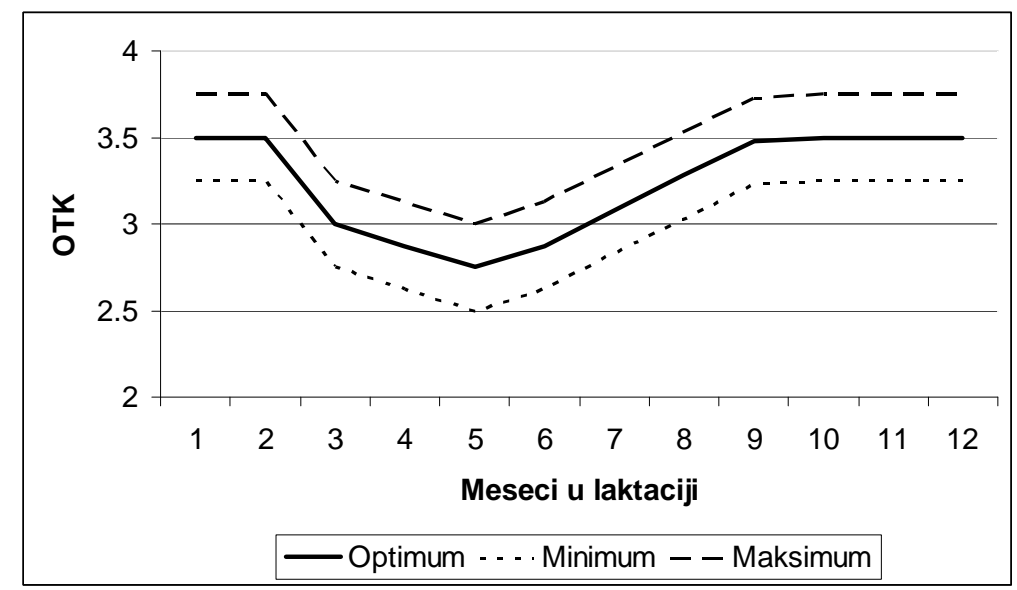

Graph 1. Optimal value of the body condition score with limit values

Fat cows are exposed to risk of incidence of metabolic problems subsequent to calving. Optimal body condition of dry cows should be between scores 3,00 and 3,75. Risk of problems can be avoided when cows have scores from 3,25 to 3,50. In early lactation, cows loose body condition. Body condition lost during this period can be maximum 1,00 of BCS (Grubić and Adamović, 2003; Grubić et al., 2005).

Cows loose body condition under normal conditions mostly from 4 to 6 weeks. Body condition in moderate values increases gradually during the period from 7 to 12 weeks. Value of the gradually recovered body condition in the period of 6 weeks when energy balance becomes positive is 0,20 points. Cows in the first 100 to 120 days of lactation should have BCS of 2,50 to 3,25 . BCS from 200th day of lactation to dry period should be between 2,75 and 3,50 . Nutrition in the dry period should ensure score between 3,25 and 3,50. It is necessary that the nutrition should be formulated and harmonized to production of each cow. In this way there are no possibilities for minimal metabolic disorders. Nutrition of cows in the dry period and in the period of early lactation 
has considerable effect on fertility results. Balanced diet is very important for dry cows and cows in lactation. Such diet enables high milk production, good quality of milk and successful reproduction. As on of the reasons of disturbed fertility is high level of milk production, and consequence is higher stress susceptibility of such cows (Grubić et al., 1994; Grubić et al., 1995; Grubić et al., 1997).

Greater loss of body mass in early lactation leads to prolongation of the period before first insemination, prolongation of the service period and calving interval. Longer service period causes prolongation of lactation and reduction of natural milk production. Final consequences are early culling and short productive life of cows.

High correlation between BCS and realized production results precisely indicates to the quantitative character of the method. Therefore it can be subject of processing using mathematical-statistical procedures and methods. Possibility of valuing of energy (nutritive) status and efficiency of nutrition of high yielding cows using BCS recommends this system for practical use in technological programs on cattle farms.

\section{Conclusion}

Body condition shows the amount of body reserves in the organism at cows disposal in all periods and phases of production cycle. Body reserves are mainly in the form of fat and less in the form of muscle tissue.

Body condition score is system with scale of scores used to evaluate the quantity of body reserves (fat and muscles) on specific body (anatomical) regions in live animals. Changes in the body condition score are related to changes of the live weight of heads of cattle and changes in composition of body tissues in high yielding cows.

Many researches in production conditions indicate that changes in the body condition have effect on health and productivity of high yielding cows. Quick loss of body condition after calving can be related to great problems when certain metabolic disturbances occur, irregular fertility and other health problems.

Body condition of cows is result of achieved production, consumption of dry matter in feeds contained in daily ration and general health condition.

Excessive body condition exhibited as fat cow syndrome is related to complex digestive, metabolic, reproductive, infectious and other systematic problems at calving and afterwards, as well as in the next lactation.

By regular scoring of body condition we have at our disposal very concrete information useful for management of all processes in the herd. 
Nutrition is the key factor in this aspect. In order for production in herd to be optimal it is necessary to maintain the body condition on optimal levels in every phase of production cycle.

\title{
OCENA TELESNE KONDICIJE VISOKOMLEČNIH KRAVA
}

\author{
G. Grubić, Ž. Novaković, S. Aleksić, Lj. Sretenović, V. Pantelić, D. \\ Ostojić-Andrić,
}

\section{Rezime}

Postojeći problemi u proizvodnji mleka, rezultatima reprodukcije i zdravstvenom stanju visokoproizvodnih krava mogu da se dovedu u vezu sa primenjenom tehnologijom ishrane.

Važno pitanje u tehnologiji ishrane visokomlečnih krava predstavlja količina raspoložive energije (hrana, depoi masti, mišići) u ključnim fazama proizvodnog ciklusa (period zasušenja i rane laktacije). Deficit energije u kritičnim periodima proizvodnog procesa može da dovede do ozbiljnih poremećaja u proizvodnji, zdravlju i reprodukciji

U početnoj fazi proizvodnje mleka najkritičniji je period maksimalne dnevne proizvodnje. Negativan bilans energije najizraženiji je u vrhu laktacije. Visok gubitak energije na račun telesnih rezervi predstavlja veliko opterećenje za metabolizam krava. Obezbeđenje adekvatne količine energije je složen uslov za svaku fazu proizvodnog ciklusa.

OTK je subjektivan metod koji vizuelno i opipavanjem vrednuje količinu potkožne telesne masti. OTK je koristan alat za upravljanje mlečnim stadom. Idealna telesna kondicija je rang koji je u funkciji toka i faze laktacije. Procena rezervi energije $u$ organizmu utvrđena preko OTK $u$ osnovi predstavlja hranidbeni status grla vrednovan preko deponovanog masnog tkiva, pri čemu telesni okvir i masa grla imaju sekundaran značaj.

Jedan od sistema za OTK krava koji je značajan za praksu je američki Virdžinija sistem modifikovan po Edmodsonu. Sistem za OTK kreiran je u obliku mape (karte) za ocenu visokomlečnih krava.

Mapa je precizno pripremljena za svaki telesni region i polje koji se može smatrati važnim u dodeli ukupne OTK krave. Tri velika telesna regiona (slabine, karlica i koren repa) podeljena su osam polja na telu krave (slabine imaju četiri polja; karlica ima tri polja; koren repa ima jedno polje). Svako telesno polje se posebno ocenjuje i koristi kao pokazatelj telesne kondicije. Svako grlo ocenjeno je individualno za promene nivoa ocene duž skale od 1 do 
5. Kontinuirano se koristi povećanje od 0,25 delova poena. Ceo sistem OTK funkcioniše sa 17 nivoa u okviru ukupne skale ocena posmatrane u intervalu od minimalne ocene $\mathrm{u}$ iznosu $1 \mathrm{i}$ maksimalne u iznosu 5. Ocena 1 pokazuje mršavu kondiciju. Ocena 5 pokazuje izrazito tovnu kondiciju. Svaka faza proizvodnog ciklusa ima svoju optimalnu ocenu.

Pod normalnim uslovima krave treba da gube telesnu kondiciju najviše od 4 do 6 nedelja. U skromnim vrednostima telesna kondicija postepeno se vraća u periodu od 7 do 12 nedelje. Krave u prvih od 100 do 120 dana laktacije treba da imaju ocenu između od 2,50 do 3,25. Ocena telesne kondicije od 200 dana laktacije do perioda zasušenja treba da je između 2,75 i 3,50. Ishrana u periodu zasušenja treba da osigura ocenu između 3,25 i 3,50.

Mogućnost vrednovanja energetskog (hranidbenog) statusa i efikasnosti ishrane visokomlečnih krava pomoću OTK preporučuje ovaj sistem za praktičnu primenu u tehnološkim programima na govedarskim farmama.

Ključne reči : ocena telesne kondicije, bilans energije, ishrana, proizvodnja, zdravlje, plodnost

\section{References}

ADAMOVIĆ,M., STOIĆEVIĆ,LJ., SRETENOVIĆ $\quad$ LJ., GRUBIĆ,G., ZEREMSKI,D., NEGOVANOVIĆ,D. (1992): Efikasnost korišćenja novih izvora proteina i energije u obrocima visokoproduktivnih krava. V. Savetovanje Veterinara Srbije. Kratki sadržaji radova. Str.: 5-6. Kopaonik.

DOMECQ, J. J., SKIDMORE, A. L., LLOYD, J. W. AND KANEENE, J. B. 1997. Relationship between body condition scores and milk yield in a large dairy herd of high yielding Holstein cows. J. Dairy Sci. 80:101.

EDMONSON, A. J., LEAN, I. J., WEAWER, L. D., FARVER, T. AND WEBSTER G. 1989. A body condition scoring chart of Holstein dairy cows. J. Dairy Sci. 72:68.

FERGUSON, J.D, GALLIGAN,D.T., THOMSEN N. (1994): Principal Descriptors of Body Condition Score in Dairy Cattle. J Dairy Sci 1994;77:2695703.

GARNSWORTHY P.C., TOPS, J.H. (1982): The effect of body condition of dairy cows at calwing on their food intake and performance when given complete diets. Animal Production, 35, 113-119.

GRUBIĆ,G., ADAMOVIĆ,M., SRETENOVIĆ LJ., STOIĆEVIĆ,LJ., JOVANOVIĆ,R. (1994): Savremeni aspekti normiranja proteina u ishrani visokomlečnih krava. Zbornik radova VIII Savetovanja agronoma i tehnologa. MP "INI Agroekonomik" d.d. Str.: 66-71. Smederevo. 
GRUBIĆ,G., HRISTOV,S., ADAMOVIĆ,M. (1995): Uticaj proteina u obroku na reprodukciju kod mlečnih krava. Zbornik kratkih sadržaja radova. VIII Savetovanje veterinara Srbije. Str.: 127-128. Zlatibor.

GRUBIĆ,G., ADAMOVIĆ,M., $\quad$ STOIĆEVIĆ,LJ., JOVANOVIĆ,R., SRETENOVIĆ LJ. (1997): Uticaj izvora proteina u obroku krava na proizvodnju i sastav mleka. Arhiv za poljoprivredne nauke. Vol. 58. Sv. 207. No. 3-4. Str.: 21-30. Beograd.

GRUBIĆ,G., STOJKOVIĆ,M., VITOROVIĆ,D., MEKIĆ,C. (1997): Ishrana i telesna kondicija ovaca u proizvodnom ciklusu. Savetovanje stručnog odbora za ovčarstvo i kozarstvo. 3-5. 12.1997. Divčibare. Poljoprivredne aktuelnosti. Br. 3-4. Str.: 117-122. (1998) Institut za primenu nauke u poljoprivredi. Beograd.

GRUBIĆ,G., ADAMOVIĆ,M., KOLJAJIĆ,V., ĐORĐEVIĆ,N. (1999): Ishrana krava i ocena telesne kondicije. XIII Savetovanje agronoma, veterinara i tehnologa. Zbornik naučnih radova 1999. Vol. 5. Br. 1. Str.: 447-456. INI PKB Agroekonomik. Aranđelovac.

GRUBIĆ,G., ADAMOVIĆ,O., STOJANOVIĆ,B., ĐORĐEVIĆ,N. (2003): Savremeni aspekti u normiranju potreba u proteinima za muzne krave. 3 . Simpozijum: Ishrana, reprodukcija i zaštita zdravlja goveda. Vrbas. 2327.09.2003. Veterinarski glasnik. Vol. 57. Br. 3-4. Str.: 101-112. Beograd. GRUBIĆ,G., ADAMOVIĆ,M. (2003): Ishrana visokoproizvodnih krava. (Drugo, izmenjeno izdanje): Institut PKB Agroekonomik. Beograd. Beograd.

GRUBIĆ,G, ĐORĐEVIĆ,N. (2005): Koncentrati u ishrani muznih krava. XI Međunarodni simpozijum Tehnologija hrane za životinje. Obezbeđenje kvaliteta. Str. 140-148. Concentrates in dairy cows nutrition. XI International Feed technology symposium. Quality assurance. Str. 233-241. 30.05.03.06.2005. Vrnjačka Banja.

GRUBIĆ,G., RADIN D., ĐORĐEVIĆ,N., ADAMOVIĆ,O. (2005): Varenje, resorpcija, promet i korišćenje hranljivih materija kod visokoproizvodnih krava. Zbornik radova 4. simpozijuma. Ishrana, reprodukcija i zaštita zdravlja goveda: Etiopatogeneza i dijagnostika poremećaja metabolizma i reprodukcije goveda. Str. 39-54. 27.09-01.10.2005. Subotica.

HUTJENS, M.F. (2005): Proceedings of the 7 Western Dairy Management Conference _ March 9-11, 2005; Reno, NV:71-76.

LACATERĀ N., SCALIA D., BERNABUCCI U., RONCHI B., PIRAZZI D., AND NARDONE A. (2005): Lymphocyte Functions in Overconditioned Cows Around Parturition. J. Dairy Sci 2005; 88:2010-2016

LOTTHAMER, K.H. (1991): Uticaj i posledice neizbalansirane ishrane na zdravlje i plodnost mlečnih krava. Zbornik predavanja 20-tog seminara za inovaciju znanja veterinara, str 71-120.

LOWMAN, B. G., N. SCOTT, AND S. SOMERVILLE. 1976. Condition Scoring of Cattle. rev. ed. Bull. East of Scotland College of Agriculture, No. 6. 
LOEFFLER, S.H., DE VRIES, M.J. AND SCHUKKEN, Y.H. (1999):

The Effects of Time of Disease Occurrence, Milk Yield, and Body Condition on Fertility of Dairy Cows. J Dairy Sci 82:2589-2604

MEKIĆ,C., STOJKOVIĆ,M., GRUBIĆ,G. (2001): Uticaj kondicije ovaca u momentu oplodnje na broj dobijene jagnjadi pri partusu. Zbornik radova simpozijuma "Naučna dostignuća u stočarstvu-2001". 1115.06.2001. Herceg Novi. Savremena poljoprivreda. Vol. 50. Br. 3-4. Str.: 47-49. Novi Sad.

MORROW, D.A. (1975) Fat Cow Syndrome. Journal of Dairy Science 1975. Vol. 59, No. 9

PRYCE J.E., AND LOVENDHAL P. (1999). Options to reduce vulnerability to metabolic stress by genetic selection. Pages 119-128 in Metabolic Stress in Dairy Cows. Br. Soc. Anim. Sci. Occasional Publ. 24.

ROSELER D.K. (1998): Dry matter intake of dairy cattle: Prediction, performance and profit. Tri-State Nutrition Conference, Fort Wayne, IN, 97120.

WILDMAN, E. E., JONES G. M., WAGNER P. E., BOWMAN R. L., TROUTT, H. F. AND LESCH, T. N.. (1982). A dairy cow body condition scoring system and its relationship to selected production characteristics. J. Dairy Sci. 65:495. 